\title{
Vocational Education: A Missing Link for the Competitive Graduates?
}

\author{
Sukardi $^{1}$, Wildan $^{1} \&$ Muh. Fahrurrozi ${ }^{2}$ \\ ${ }^{1}$ The Faculty of Teacher Training and Education, University of Mataram, Mataram, Indonesia \\ ${ }^{2}$ University of Hamzanwadi, Selong, Indonesia \\ Correspondence: Sukardi, The Faculty of Teacher Training and Education, Postgraduate, University of Mataram, \\ Mataram, Indonesia.
}

Received: November 16, 2018

Accepted: December 30, 2018

Online Published: October 25, 2019

doi:10.5539/ies.v12n11p26

URL: https://doi.org/10.5539/ies.v12n11p26

\begin{abstract}
The present study is based on the issue of the competitiveness of vocational education graduates. This condition is likely due to the irrelevance between the content or the competencies developed and the superiority of the regions (Regency/Municipality). Therefore, the first step to improve the competitiveness of the graduates is evaluating the accordance of their competencies developed by the vocational education in every region of the regency or municipality. This study used a policy evaluation method formulated in the form of Service Quality (ServQual) by taking all vocational schools in 6 (six) sample districts/cities. The research instruments used are in-depth interview and document studies. The data were then analyzed using Location Quotient (LQ), growth ratio, and Overlay (Ovr) analysis. It indicates that the content of vocational education reflected in the competence of skills developed was not relevant to the issues or potential of each district/city. This condition causes the low competitiveness of vocational education graduates, both in entrepreneurship and competitiveness in the national and international labor market.
\end{abstract}

Keywords: vocational education, competitiveness

\section{Introduction}

\subsection{Background of Study}

The main issue of this study is concerned with the competitiveness of vocational education graduates in Indonesia. It indicates that in the labor market, most graduates tend to seek instead of creating job vacancies (Sukardi \& Wardana, 2016). The Central Bureau of Statistics of Indonesia (2017) noted a total of 1,621,402 unemployed vocational graduates $(23 \%)$. This condition is understandable because the goal of the vocational education is to prepare the graduates be ready to enter labor market. The link and match between the graduates of the vocational schools and industries or labor market has been a popular thesis that are always echoed in the development of vocational education (Djojonegoro, 1998). Vocational education should be adapted to the needs of the industry (Soenarto, Amin, \& Kumaidi, 2017). The problem is the demand of the industrial/labor market is much lower than the number of the annual vocational graduates (Sumarno, 2009), besides the rapid change of job vacancies. If its parameter is only based on the link and match to industry or labor market, it can be predicted that there will be a great number of unemployed vocational education graduates, and at the same time, the skills offered by the vocational education are homogeneous and not suitable with the regional issue or the priority base sectors (Sukardi \& Wardana, 2016).

Meanwhile, theoretically, the competitiveness is not only measured from the rate of absorption in labor market, but also their abilities to create new businesses and to possess their own businesses (Charney \& Libecap, 2000). This criterion based on Bikse, Rivža, and Latvian's (2013) study is recognized as the characteristics of competitive graduates. Zhang (2009) also emphasizes that one of the goals of the vocational education is to strengthen the students' practical application skills. Meanwhile, the graduates' competitiveness also depends on the ability of the institution to create and maintain its competitive superiority (Bikse et al., 2013; Dwyer \& Kim, 2003). Similarly, Porter $(1990 ; 1998)$ states that competitive superiority is determined by a number of factors, such as: 'related and supporting industries', and 'strategy, structure and rivalry'. Based on Porter's (1990; 1998) perspective, it can be concluded that vocational education graduates' competitiveness is low because the vocational competencies developed do not meet the regional issues or advantage ('resource-based view'). Its implication brings about the unavailability of specific competencies as the uniqueness of the vocational 
education. Through 'resource-based view', vocational education will have 'differential capabilities' leading to a 'sustainable competitive advantage' (Etzkowitz, 2004). By so doing, vocational education is expected to have a competitive advantage that is difficult to imitate as reported by Ozgen (2011).

This 'resource-based view' has been a characteristic of Indonesia as indicated by the six national development corridors and/or some industrial areas development (Bappenas, 2015). For examples, the development tourism areas in Lombok, Agro (cocoa) industry in Padang Pariaman, CPO-based biodiesel in Medang Kampai Riau, Manufacturing and Textiles in Kendal, Processing agricultural and marine produce in East Lombok, and so on (Bappenas, 2015). Therefore, if the development of educational competencies of the vocational education is directed to the nominated sectors (knowledge capitalization), graduates competitiveness will be achieved because it is directed to create new entrepreneurship or own self-business, not only to fulfill the need of the industrial world. In the context of higher education, some higher educations which implement knowledge capitalization proved to be effective to produce competitive graduates which then lead to a better economic growth (Etzkowitz, 2013; Wong, Ho, \& Singh, 2007).

The question arises whether the advantage base sector of each region in Indonesia has been identified and considered as a reference for the development of vocational education competencies? Accordingly, the first phase in attempt to increase the competitiveness of the graduates is to evaluate the policy dealing with the match of the competencies to be developed in the vocational educations with the nominated base sector of each region. From a practical point of view, the information about the results of the evaluation will be used as a reference to revitalize the skills of vocational education in Indonesia to improve the competitiveness of the vocational education graduates. Referring to theoretical perspective, this study is expected to construct Porter' theory on competitiveness $(1990 ; 1998)$ in Indonesia, both for the dimensions of 'input factors', 'demand conditions', 'related and supporting industries', and 'strategy, structure and rivalry'.

\subsection{Review of Literature}

It seems that Charles Prosser's theory (Camp \& Hillison, 1984) as also quoted by Sumarno (2009) still characterizes the development of vocational education in Indonesia. One of the philosophical points of vocational education which was then adopted in Indonesia was "vocational education will be efficient if an environment suitable with the real conditions in which the graduates work is provided" (Sumarno, 2009). This thesis indicates that the competitiveness of graduates of vocational education is measured from their ability to fulfill the industrial and/or the labor market.

The impact is the gap between the needs of the industrial world and the number of graduates. Meanwhile, competitiveness is not only measured through the absorption of graduates in the industrial world, but also the ability to create new businesses or their own businesses (Bikse et al., 2013) and/or have competitive advantages (Porter, 1990; 1998) based on each regional advantages. In the meantime, creating self-business based on the potential or regional advantages is the essence of entrepreneurship (Lee \& Peterson, 2000). Entrepreneurship is a significant factor in the national competitiveness (graduates), because it is the main agent in driving economic change (Wong, Ho, \& Autio, 2005; Acs \& Amorós, 2008; Koellinger \& Roy-Thurik, 2012).

However, to grow entrepreneurship, an entrepreneurial environment is needed in the form of an entrepreneurial school that triggers its students to create businesses (Etzkowitz \& Zhou, 2008) by utilizing the superior sectors of each region ('resource-based view'). This resource-based view is the hallmark of Indonesia with the existence of 6 national development corridors and/or some industrial areas development (Bappenas, 2015). Based on 'resource-based view', it is also a construction of Dimond Porter's competitiveness factor (Porter, 1990, 1998), especially 'input factors', and 'related and supporting industries'. 'Input factors', for example, will be related to the suitability of developing vocational education with the potential or leading sectors of the region.

Actually, in the region, the superior base sector reflects that it is not only capable of supporting its needs, but also being able to support other regions (Mankiw, 2012, p. 556). The advantage base sector in each region is a driver of economic growth and contributes to the regional economy. Thus, to manage the superior sector into a productive business/entrepreneurship, human resources that are able to manage and develop it are needed, so that it is economically valuable. This is the role of vocational education which prepares competitive human resources, especially in creating their own business through the utilization of superior base sectors in each region.

However, it was alleged that the development of vocational education expertise in Indonesia is not based on the nominated base sector. This is supported by the fact that the results of several studies showing that the development of vocational education competencies in Indonesia is more focused on the needs of the industries or companies (Soenarto et al., 2017; Hasanah \& Malik, 2015; Sumarno, 2009), not based on the superior base sector. This condition makes the graduates competitiveness low due to the limited ability of the industrial world to absorb the 
graduates. In order to adapt the latest demands and rapid economic development, Zhang (2009) suggests that education be improved in order to solve the existing social problems.

A strategy for the improvement, policy evaluation is needed regarding the development of vocational education expertise in Indonesia. The evaluation begins with the analysis of the superior base sectors of each region and then correlate with the field of vocational education expertise implemented. To analyze the nominated base sector, Overlay analysis (Miller et al., 1991) which combines the analysis of location quotient (thereater LQ) and growth ratio models (thereafter GRM) is relevant to be used in evaluating the suitability of vocational education competencies with the advantage base sectors. In principle, LQ is applied to measure the concentration of specialization of economic activities through a comparative approach. Meanwhile, the GRM is a method to determine which economic base sector is potential in increasing the regional economic growth (Basuki \& Gayatri, 2009). Through this way, the development of vocational education expertise is more appropriate, so that it has a competitive advantage. There is almost no research that applies this analysis model to measure competitive advantage in education, except for the industrial sector in China (Li et al., 2015), food crop farming in Bantul Indonesia (Mulyono \& Munibah, 2016), economy in Jambi Indonesia (Hardiani \& Lubis, 2017).

\section{Methods of Research}

\subsection{Research Types}

The principle of this study focuses on the attempt to provide recommendation for the improvement of the content or substance of vocational education competencies in order to create competitive graduates, particularly in developing self-entrepreneurships. Thus, the present study is a type of policy evaluation research that focuses on policy content (Purdon et al., 2001). This evaluation is formulated in the form of Service Quality (ServQual) as developed by Parasuraman et al. (1994), Berry and Parasuraman (2004) to study the suitability of field or competencies with the territorial or regional superiority base sector issues. The quality of service in this study is not measured based on the conformity between expectations and reality as suggested by the Parasuraman et al.'s (1994) concept, but is measured according to the suitability of expertise developed with the territorial or regional superiority sector issues.

The study was conducted with policy content analysis through the following phases, namely: (1) determining the data sources based on the research problems. The main data sources of this study are the Central Bureau of Statistics Agency (both the Regency/ Municipality level and the West Nusa Tenggara Province, and the Indonesian national level), the Education Office (Regency/Municipality and West Nusa Tenggara Province), and the data from the other informants; (2) Collecting the existing data, such as: Regency/City and Provincial strategic educational plans in West Nusa Tenggara; legal permission of school establishment, and Regency/Municipality and Province Gross Regional Domestic Product (thereafter GRDP) data at constant prices, and also conducting in-depth interviews to research informants; (3) sorting-out the data based on the group of data needed; and (4) conducting quantitative and qualitative data analysis (Ary, Jacobs, \& Razavieh, 2010).

\subsection{Data Collection Instruments}

The instruments used in this research were in-depth interviews and document review. The document review was done at the School level by reviewing the curriculum structure, the level of the District/City Education Office and the Province of West Nusa Tenggara by analyzing at the Strategic Plan and the legal establishment as well as the Central Agency on Statistics to study the Gross Regional Domestic Product (GRDP) of the Cities and Districts in West Nusa Tenggara Province based on the constant prices. In-depth interviews were done to several informants (thereafter INF), such as The Division Head of Vocational High School of Education, Youth, and Sport office of West Nusa Tenggara Province (INF.1), the division head of the primary and secondary school of Education, Youth, and Sport office of West Sumbawa District (INF .3), Head of Vocational School of 2 Mataram (INF.3), the division head of Primary and Secondary Education of Education, Youth and Sports Department of Mataram Municipality (INF.4), and the Head of West Lombok Regional Development Planning Agency (INF.5). Interviews were conducted to deepen the establishment policy of vocational education including the competence or expertise.

\subsection{Validity and Reliability}

The data derived from the Central Bureau of Statistics were not assessed its validity and reliability again because both of them have been standardized, validated and authorized by the institution. The data issued by the institution have been officially authorized by all relevant institutions in Indonesia and have been the reference for the world banks. The qualitative data collected with interviews were validated with qualitative criteria as Ary et al. (2010) suggests, namely, credibility, transferability, dependability, and confirmation. Credibility was conducted through source triangulation (among informants) and data collection techniques (document review 
with in-depth interviews). Transferability criteria were made by having a "detailed description", to report the results of research accurately refers to the research problem. Dependability criteria were made by conducting scientific consultations with colleagues to review the activities and the results of research. Confirmation criteria were made by field note-taking, interview transcripts, recorded documents, and the other notes.

\subsection{Data Analysis}

Data analysis employed qualitative analysis and analysis of the concordance of competency in the field of expertise with the region's superior base sectors. To determine the advantage base sector, an analysis using Overlay technique was used, namely an analysis that combines the LQ technique with the GRM model (Miller et al., 1991). This LQ method was used to identify the leading commodities/sectors which have also been done by Li et al. (2015). Besides the leading sectors, the analysis is also directed to the growth and contribution of each sector to the regional economy. Therefore, the GRM analysis is used as an analysis of the leading and potential economic sectors which have potential growth in the economic structure of the region. The GRM analysis approach is divided into two ratios, namely the analysis of the Reference Area Growth Ratio (thereafter RAG) and the Study Area Growth Ratio (therefter AGR). RAG is a comparison between the GRDP growth rate in the business sector i in the reference area (West Nusa Tenggara Province) and the total GRDP growth rate in the reference area (West Nusa Tenggara Province). AGR is a comparison between the GRDP growth rate of business sector in the study area (District/City) and the total growth rate of GRDP in the reference area (West Nusa Tenggara Province). The GRDP used is GDP with constant prices from 2012 to 2016. The criteria for the overlay analysis used in this study are modified from 8 (eight) parameters (Miller et al., 1991) to 3 (three), namely: +++ (contribution and high growth and is a leading base sector), -++ (one of the criteria has a weakness/low category), and ---- (contribution and low growth and not a superior base sector).

\section{Results and Discussion}

\subsection{Results}

The data from the Central Bureau of Statistics of West Nusa Tenggara Province (2017) showed that the economic growth had increased from $66,340,812,400$ in 2012 to $94,537,700,000$ in 2016. The largest contributing sector is mining and quarrying sector, which reaches $22.51 \%$, while in the analysis of the Central Bureau of Statistics of West Nusa Tenggara Province, 2017. The RAG, SAG, and LQ overlays show that each region has its own leading sector. The construction sector and other services (such as households and tourism sectors) are almost even distributed across all samples in the research areas (see Table 1 and Figure 1). 
Table 1. Overlay RAG, SAG, and LQ economy of regency/municipality research sample year 2012-2016

\begin{tabular}{|c|c|c|c|c|c|c|c|c|c|c|}
\hline \multirow{2}{*}{ No } & \multirow{2}{*}{ RAG } & \multicolumn{3}{|c|}{ Central Lombok Regency } & \multicolumn{3}{|c|}{ East Lombok Regency } & \multicolumn{3}{|c|}{ West Sumbawa Regency } \\
\hline & & SAG & LQ & Ovr & SAG & LQ & Ovr & SAG & LQ & Ovr \\
\hline 1 & 1.00 & 1.05 & 1.17 & +++ & 1.73 & 1.28 & +++ & 0.77 & 0.43 & --++ \\
\hline 2 & 3.00 & -9.26 & 0.22 & +-- & -8.19 & 0.32 & +-- & 3.81 & 27.9 & +++ \\
\hline 3 & 1.05 & 1.12 & 1.28 & +++ & 0.62 & 1.95 & +-+ & 1.44 & 0.38 & +-+ \\
\hline 4 & 2.69 & 1.66 & 0.89 & +-+ & 1.64 & 1.06 & +++ & 0.12 & 0.82 & +-- \\
\hline 5 & 1.52 & 1.05 & 1.32 & +++ & 1.11 & 1.24 & +++ & 1.06 & 1.45 & +++ \\
\hline 6 & 1.89 & 0.93 & 0.86 & +-- & 1.04 & 1.22 & +++ & 1.11 & 0.86 & +++ \\
\hline 7 & 0.96 & 0.86 & 2.52 & -+- & 0.83 & 0.64 & --- & 0.06 & 0.56 & --- \\
\hline 8 & 1.90 & 0.94 & 0.60 & +-- & 0.89 & 0.50 & +-- & 0.68 & 0.98 & +-- \\
\hline 9 & 0.93 & 0.94 & 0.64 & --- & 1.03 & 0.75 & -+- & 0.99 & 0.83 & --- \\
\hline 10 & 1.78 & 0.87 & 0.86 & +-- & 0.91 & 0.66 & +-+ & 0.58 & 1.27 & +-+ \\
\hline 11 & 1.46 & 1.05 & 1.08 & +++ & 1.15 & 0.99 & +-+ & 0.88 & 1.08 & +-+ \\
\hline \multirow{2}{*}{ No } & \multirow{2}{*}{ RAG } & \multicolumn{3}{|c|}{ Mataram Municipality } & \multicolumn{3}{|c|}{ West Lombok Regency } & \multicolumn{3}{|c|}{ North Lombok Regency } \\
\hline & & SAG & LQ & Ovr & SAG & LQ & Ovr & SAG & LQ & Ovr \\
\hline 1 & 1.00 & 0.73 & 0.19 & +-- & 0.91 & 0.95 & +-- & 0.70 & 1.59 & +-+ \\
\hline 2 & 3.00 & -0.28 & 0.00 & +-- & -9.26 & 0.36 & +-- & -9.73 & 0.20 & +-- \\
\hline 3 & 1.05 & 1.50 & 2.26 & +++ & 1.12 & 1.09 & +++ & 1.16 & 0.33 & +-+ \\
\hline 4 & 2.69 & 1.69 & 1.43 & +++ & 1.66 & 1.23 & +++ & 1.65 & 1.44 & +++ \\
\hline 5 & 1.52 & 1.55 & 1.18 & +++ & 1.05 & 1.45 & +++ & 1.05 & 0.98 & +-+ \\
\hline 6 & 1.89 & 1.37 & 1.55 & +++ & 0.93 & 1.02 & ++- & 0.80 & 1.08 & +-+ \\
\hline 7 & 0.96 & -0.82 & 0.91 & --- & 0.86 & 1.42 & -+- & 0.76 & 0.81 & --- \\
\hline 8 & 1.90 & 1.35 & 0.85 & +-+ & 0.94 & 3.84 & ++- & 0.94 & 3.28 & +-+ \\
\hline 9 & 0.93 & 1.20 & 3.05 & -++ & 0.94 & 0.92 & --- & 0.53 & 0.86 & --- \\
\hline 10 & 1.78 & 1.34 & 2.56 & +++ & 0.87 & 0.66 & +-- & 0.79 & 1.51 & +-+ \\
\hline 11 & 1.46 & 1.82 & 2.44 & +++ & 1.05 & 1.21 & +++ & 1.13 & 1.09 & +++ \\
\hline
\end{tabular}

1. Agriculture, Forestry \&Fishing; 2. Mining \& Quarrying; 3.Manufacturingn; 4. Electricity \& Gas; 5.Construction; 6.Trade; 7.

Detail: Transportation \& Storage; 8. Accomodation \& food Service Activities; 9. Financial \& Insurance Activities; 10. Bussiness Activities; and 11. Other Service Activities

Data Management Central Bureau of Statistics of West Lombok Regency (2017), Central Bureau of Statistics of North Lombok

Source: Regency (2017), Central Bureau of Statistics of Central Lombok Regency (2017), Central Bureau of Statistics of East Lombok Regency (2017), Central Bureau of Statistics of Mataram Municipality (2017), and Central Bureau of Statistics of West Sumbawa Regency (2017).

Data shown in Table 1 reflect the areas that have competitive advantages. The agricultural sector is a superior base which provides a high growth and contribution to the economic structure in Central Lombok and East Lombok Districts. Meanwhile, the mining sector is a leading base sector with high growth and contribution to the economic structure in West Sumbawa Regency. The electricity and gas procurement sector have been well distributed as the leading base to all sample districts, except North Lombok, East Lombok and Sumbawa Regencies. Likewise, the construction sector is a superior base with a fairly high growth and contribution to the economy in all districts, except for North Lombok Regency. Other sectors that show competitive advantage are the other service sectors. Such services are related to household activities including tourism services. The tourism sector has developed quite rapidly because it is the second sector that contributes the second largest after the agricultural sector to Gross Regional Domestic Product (GRDP) in West Lombok District (Central Bureau of Statistics of West Lombok Regency, 2017). 


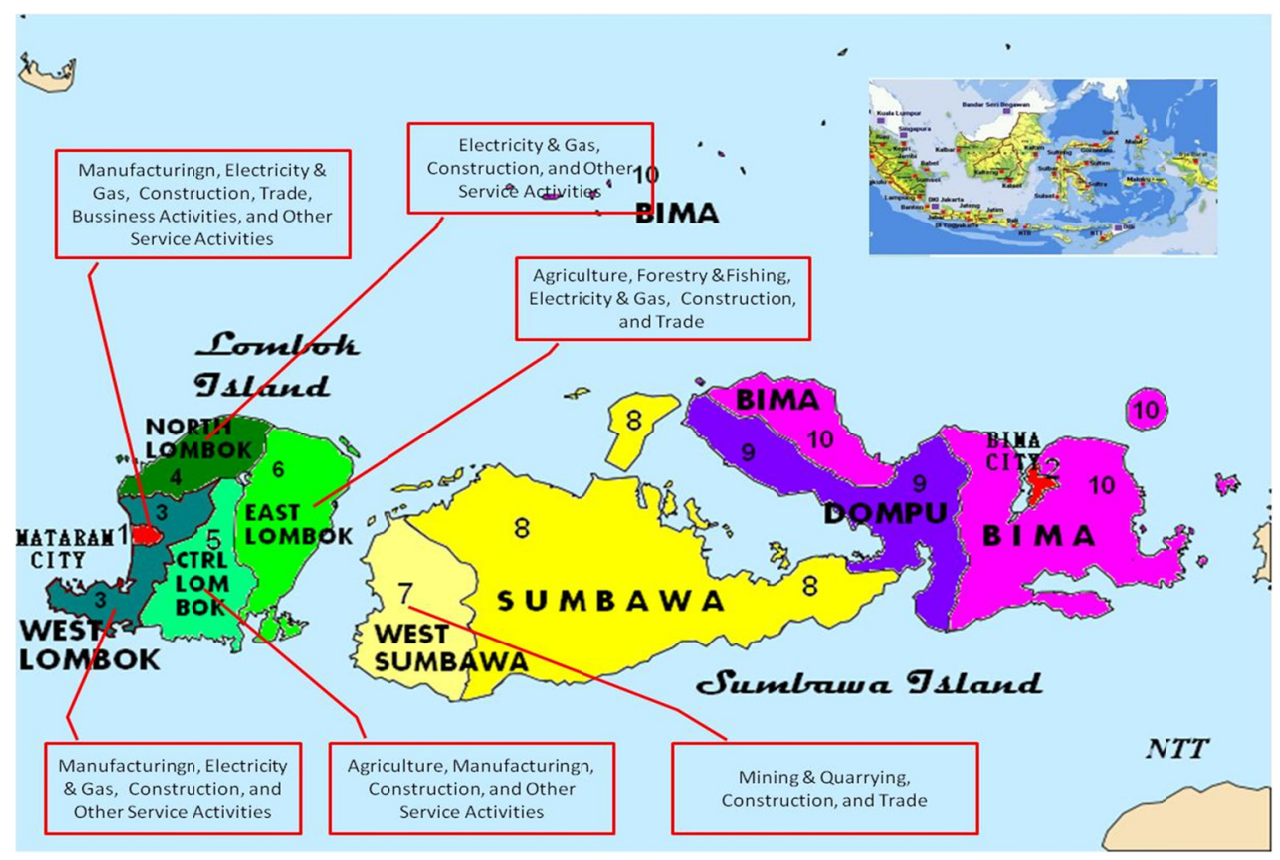

Figure 1. Map of the featured leading sector of each study sample area

The findings above reflect that each region in Indonesia has a superior base sector that has its own characteristics. The results of Wahyuningtyas, Rusgiyono, \& Wilandari's (2013) study, for example, places the agricultural and mining sectors as the leading base sectors in Kendal Regency, Central Java Province, Indonesia. Similarly, the study of Mulyono and Munibah (2016) place paddy rice as a superior base sub-sector in Bantul Regency, Special Region of Yogyakarta, Indonesia. In Jambi City, the electricity and gas, buildings, trade and health care sectors are the leading sectors that contribute to the economy as reported by Hardiani and Lubis (2017).

The results of the analysis above show the competitive advantages of each region, so that it needs to be sustained by the quality of human resources. The question, "Are the fields or competencies developed by the vocational education institutions correspond to the leading base sectors?" The data in Table 2 visualize the suitability of the field or skills developed by the institution with the leading base sector of each research sample area. 
Table 2. Relevance of Vocational education skills with the regional leading sector

\begin{tabular}{|c|c|c|c|c|c|}
\hline Regency/Municipality & Featured Leading Sector & $\begin{array}{c}\text { Number of Vocational } \\
\text { Education }\end{array}$ & $\begin{array}{l}\text { Expertise } \\
\text { Fields }\end{array}$ & $\begin{array}{c}\text { Number of Relevant Voc. } \\
\text { Programs }\end{array}$ & Percentage \\
\hline \multirow{6}{*}{ Mataram } & Manufacturing & \multirow{6}{*}{10} & \multirow{6}{*}{56} & \multirow{6}{*}{27} & \multirow{6}{*}{48.21} \\
\hline & Electricity \& Gas & & & & \\
\hline & Construction & & & & \\
\hline & Trade & & & & \\
\hline & Bussiness Activities & & & & \\
\hline & Other Service Activities & & & & \\
\hline \multirow{4}{*}{ West Lombok } & Manufacturing & \multirow{4}{*}{14} & \multirow{4}{*}{58} & \multirow{4}{*}{24} & \multirow{4}{*}{41.38} \\
\hline & Electricity \& Gas & & & & \\
\hline & Construction & & & & \\
\hline & Other Service Activities & & & & \\
\hline \multirow{3}{*}{ North Lombok } & Electricity \& Gas & \multirow{3}{*}{5} & \multirow{3}{*}{18} & \multirow{3}{*}{8} & \multirow{3}{*}{44,44} \\
\hline & Construction & & & & \\
\hline & Other Service Activities & & & & \\
\hline \multirow{5}{*}{ Central Lombok } & Agriculture, Forestry & \multirow{5}{*}{9} & \multirow{5}{*}{36} & \multirow{5}{*}{13} & \multirow{5}{*}{36.11} \\
\hline & \&Fishing & & & & \\
\hline & Manufacturing & & & & \\
\hline & Construction & & & & \\
\hline & Other Service Activities & & & & \\
\hline \multirow{5}{*}{ East Lombok } & Agriculture, Forestry & \multirow{5}{*}{9} & \multirow{5}{*}{62} & \multirow{5}{*}{11} & \multirow{5}{*}{17.74} \\
\hline & \&Fishing & & & & \\
\hline & Electricity \& Gas & & & & \\
\hline & Construction & & & & \\
\hline & Trade & & & & \\
\hline \multirow{3}{*}{ West Sumbawa } & Mining \& Quarrying & \multirow{3}{*}{5} & \multirow{3}{*}{18} & \multirow{3}{*}{2} & \multirow{3}{*}{11.11} \\
\hline & Construction & & & & \\
\hline & Trade & & & & \\
\hline
\end{tabular}

Average of Relevant Vocational Education Programs

Source: Processed from the primary data.

The results of the analysis as shown in Table 2 show that most of the substance or areas of expertise developed by the vocational education are not in line with the region's leading base sectors. The highest nonconformity is found in West Sumbawa Regency and the lowest in North Lombok Regency. In West Sumbawa Regency, for example, the leading sector and those that have high growth and contribution to the economy are the mining and quarrying sector. However, none of the vocational education developed such competencies in the sector. On the hand, what have been developed are office administration, computer engineering and networking, agricultural agribusiness, fisheries agribusiness, software engineering, and the like. In East Lombok Regency, it also shows the same conditions where ideally it should develop skills in the agriculture, forestry and fisheries sectors. Based on figure, it is natural that vocational education graduates are not competitive enough, both in creating new businesses and developing their own businesses, as well as in gaining opportunities in the job market. In addition, this condition has not included vocational educations which are managed independently by the community (or private) whose fields of expertise tend to be homogeneous.

All informants from the Policy Maker also acknowledged that the establishment of vocational educations and the area of expertise were not based on the results of the LQ, GRM, and Overlay analysis (INF.1, INF.2, INF.3, INF.4, \& INF.5). The establishment of the vocational education is based more on the instruction of the Government of Indonesia (through the Ministry of Education and Culture) rather than the need of the local area (INF.1 and INF.2).

"Now we want to start the welding technique class, but the availability of competent teacher is still a problem" (INF.3)

"The main reason is how to accelerate the expansion of educational access ... the Regent asked us to increase the gross enrollment rate (GER) and net enrollment rate (NER) .... we established many vocational schools .... quality issues is put on the second priority "(INF.2) 


\subsection{Discussion}

The above findings confirm that the developed competences are not relevant to the leading sectors in the local areas. This, particularly, leads to the less competitive graduates as they fail to meet the required skills/competences demanded by the business world/industries/job market (Porter, 1990; 1998). Porter (1990; 1998) further states that competitive advantages can be achieved when the competence developed is relevant to the one needed by the world of industry/job world/labor market including the region's leading sector. Therefore, vocational education should ideally have a competitive strategy through which the specific competencies related to leading sector can be achieved. The specific competencies referred to are unique competencies that are difficult to imitate by competitors (Ozgen, 2011). The findings of some studies also confirm that competence developed by vocational education failed to increase competitive advantage of the graduates. The findings of Soeharto's (2012) study, for example, indicates that the achievement of the standard competence of vocational education graduates in the province of Yogyakarta Special Region of Yogyakarta only reached 0.57. Sumarno's (2009) finding also shows that from the labor market indicator, Industrial and Technological Vocational High School (ITVHS) in Bandar Lampung city of Indonesia is still ineffective.

This inconsistency also has implications for the lack of contribution of vocational education institutions in the development of the region, as it is not sustained by human resources in the leading sector. In fact, the leading sector has become a strategic resource in developing the competence of the graduates. Etzkowitz (2004) termed the different capability of educational institutions to achieve competitive advantage. With reference to the leading sector, graduates will be able to identify opportunities to establish business as found by Bikse at al. (2013) which has not led to the contents of entrepreneurship education based on leading sectors. The study of Ghina, Simatupang, \& Gustomo (2017) also revealed the importance of strengthening educational institutions in developing their areas of expertise in accordance with the region's potential advantages.

\section{Conclusion and Suggestions}

The results of the evaluation based on the Overlay analysis indicate that the competence developed by vocational education is still not relevant to the local issue or the leading sector of each regency/municipality. Of the sampled regencies, Mataram Municipality developed the most relevant competence to the leading sector, while West Sumbawa developed the least relevant ones. This discrepancy reflects the situation where the competitive advantage in Porter's perspective, particularly on the dimensions of relevance and educational strategy, failed to be met. Unreached competitive advantage of vocational education has an impact to the competitiveness of the graduates. The implication is the importance of revitalizing fields or competency of vocational education expertise that is in line with advantages-base sectors. These advantages-base sectors are proven to be effective on significant growth and contribution to the structure of the regional economy to provide opportunities for productive business development by vocational education graduates. Theoretically, the competitive advantage of vocational education is an important variable in producing competitive graduates (both in creating new businesses and in competing in the labor market). The relevance of the education and the strategy of vocational education institutions should be addressed to the development of competencies based on the leading sectors.

\section{Acknowledgments}

Acknowledgments are addressed to the Ministry of Research of Technology and Higher Education and University of Mataram which have facilitated during the research process. Thanks also go to the team participating during the data collection process until the writing of this article.

\section{Refrences}

Acs, Z. J., \& Amorós, J. E. (2008). Entrepreneurship and competitiveness dynamics in Latin America. Small Business Economics, 31(3), 305-322. https://doi.org/10.1007/s11187-008-9133-y

Ary, D., Jacobs, L. C., \& Razavieh, A. (2010). Introduction to research in education (8th ed.). Wardswoth Cengage Learning. Canada: Nelson Education Ltd Exotic Classic.

Badan Perencanaan Pembangunan Nasional/Bappenas. (2015). Peraturan presiden nomor 2 tahun 2015 tentang rencana pembangunan jangka menengah nasional 2015-2019. Jakarta: Badan Perencanaan Pembangunan Nasional Indonesia.

Basuki, A. T., \& Gayatri, U. (2009). Penentu sektor unggulan dalam pembangunan daerah: Studi kasus di Kabupaten Ogan Komering Ilir. Jurnal Ekonomi \& Studi Pembangunan, 10(1), 34-50. http://dx.doi.org/10.18196/jesp.10.1.1280

Berry, L. L., \& Parasuraman, A. (2004). Marketing services: Competing through quality. Simon and Schuster. 
Bikse, V., Rivža, B., \& Latvian, I. B. (2013). Competitiveness and quality of higher education: graduates' evaluation. Journal of Teacher Education for Sustainability, 15(2), 52-66. https://doi.org/10.2478/jtes-2013-0011

Camp, G. W., \& Hallison. (1984). Prosser's sixteen theorems, time for consideration. Omocron: Tau Theta.

Central Bureau of Statistics of Central Lombok Regency. (2017). Gross regional domestic product of Lombok Tengah Regency by industrial origin 2012-2016. Praya: Central Bureau of Statistics of Central Lombok Regency.

Central Bureau of Statistics of East Lombok Regency. (2017). Gross regional domestic product of Lombok Timur Regency by industrial origin 2012-2016. Selong: Central Bureau of Statistics of East Lombok Regency.

Central Bureau of Statistics of Indonesia. (2017). Statistical yearbook of Indonesia 2017. Jakarta: Indonesia Central Bureau of Statistics.

Central Bureau of Statistics of Mataram Municipality. (2017). Gross regional domestic product of Mataram Municapility industrial origin 2012-2016. Mataram: Central Bureau of Statistics of Mataram Municipality.

Central Bureau of Statistics of North Lombok Regency. (2017). Gross regional domestic product of Lombok Utara Regency by industrial origin 2012-2016. Tanjung: Central Bureau of Statistics of North Lombok Regency.

Central Bureau of Statistics of West Lombok Regency. (2017). Gross regional domestic product of Lombok Barat Regency by industrial origin 2012-2016. Gerung: Central Bureau of Statistics of West Lombok Regency.

Central Bureau of Statistics of West Nusa Tenggara Province. (2017). Gross regional domestic product Nusa Tenggara Barat Province by industry 2012-2016. Mataram: Central Bureau of Statistics of West Nusa Tenggara Province

Central Bureau of Statistics of West Sumbawa Regency. (2017). Gross regional domestic product of Sumbawa Barat Regency by industrial origin 2012-2016. Taliwang: Central Bureau of Statistics of West Sumbawa Regency.

Charney, A., \& Libecap, G. D. (2000). Impact of entrepreneurship education (p. 45À60). Kansas City, MO: Kauffman Center for Entrepreneurial Leadership. Retrieved from http://www.unm.edu/ asalazar/Kauffman/ Entrep_research/e_ed_grow.pdf

Djojonegoro, W. (1998). Pengembangan sumberdaya manusia melalui sekolah menengah kejuruan (SMK). Jakarta: PT Balai Pustaka.

Dwyer, L., \& Kim, C. (2003). Destination competitiveness: determinants and indicators. Current issues in tourism, 6(5), 369-414. https://doi.org/10.1080/13683500308667962

Etzkowitz, H. (2004). The evolution of the entrepreneurial university. International Journal of Technology and Globalisation, 1(1), 64-77. https://doi.org/10.1504/IJTG.2004.004551

Etzkowitz, H. (2013). Silicon Valley at risk? Sustainability of a global innovation icon: An introduction to the Special Issue. Social Science Information, 52(4), 515-538. https://doi.org/10.1177/0539018413501946

Etzkowitz, H., \& Zhou, C. (2008). Introduction to special issue Building the entrepreneurial university: A global perspective. Science and Public Policy, 35(9), 627-635. https://doi.org/10.3152/030234208X363178

Ghina, A., Simatupang, T. M., \& Gustomo, A. (2017). The relevancy of graduates' competencies to the effectiveness of entrepreneurship education: A case study at SBM ITB-Indonesia. Journal of Entrepreneurship Education, 20(1), 1-24. Retrieved from https://www.abacademies.org/articles/therelevancy-of-graduates-competencies-to-the-effectiveness-of-entrepreneurship-education-a-case-study-at-sb m-itb--indonesia-6570.html

Hardiani, H., \& Lubis, T. A. (2017). Analysis of leading sector of Jambi City. Jurnal Perspektif Pembiayaan dan Pembangunan Daerah, 5(1), 1-12. https://doi.org/10.22437/ppd.v5i1.3853

Hasanah, H., \& Malik, M. N. (2015). Profil kompetensi kelistrikan berdasarkan klasifikasi dan kualifikasi industri untuk pengembangan pendidikan dan latihan kejuruan. CAKRAWALA PENDIDIKAN Jurnal Ilmiah Pendidikan, 34(1), 78-88. https://doi.org/10.21831/cp.vli1.4178

Koellinger, P. D., \& Roy-Thurik, A. (2012). Entrepreneurship and the business cycle. Review of Economics and Statistics, 94(4), 1143-1156. https://doi.org/10.1162/REST_a_00224 
Lee, S. M., \& Peterson, S. J. (2000). Culture, entrepreneurial orientation, and global competitiveness. Journal of World Business, 35(4), 401-416. https://doi.org/10.1016/S1090-9516(00)00045-6

Li, F., Luo, F. Z., Liu, Z., \& Li, Y. C. (2015). Based on the identification and location quotient measure law ces yulin new energy industry clusters and analysis. In Applied Mechanics and Materials (Vol. 733, pp. 960-963). Trans Tech Publications. https://doi.org/10.4028/www.scientific.net/AMM.733.960

Mankiw, N. G. (2012). Essentials of economic. Mason, OH: South-Western Cengage Learning.

Miller, M. M., Gibson, L. J., \& Wright, N. G. (1991). Location quotient: A basic tool for economic development analysis. Economic Development Review, 9(2), 65. Retrieved from https://search.proquest.com/openview/ d6011b83d027b7ad1dba29bb96b74a53/1?pq-origsite $=$ gscholar\&cbl=38209

Mulyono, J., \& Munibah, K. (2016). Pendekatan location quotient dan shift share analysis dalam penentuan komoditas unggulan tanaman pangan di Kabupaten Bantul. Informatika Pertanian, 25(2), 221-230. http://dx.doi.org/10.21082/ip.v25n2.2016. p221-230

Ozgen, E. (2011). Porter's diamond model and opportunity recognition: a cognitive perspective. Academy of

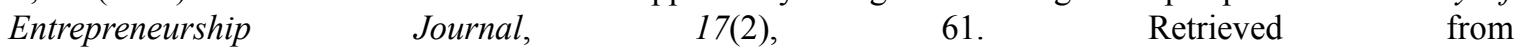
https://www.abacademies.org/articles/aejvol17no22011.pdf

Parasuraman, A., Zeithaml, V. A., \& Berry, L. L. (1994). Reassessment of expectations as a comparison standard in measuring service quality: implications for further research. The Journal of Marketing, 111-124. https://doi.org/10.2307/1252255

Porter, M. E. (1990). The competitive advantage of nations. Competitive Intelligence Review, 1(1), 14. https://doi.org/10.1002/cir.3880010112

Porter, M. E. (1998). The Competitive Advantage of Nations (with a new introduction). Basingstoke: Macmillan. https://doi.org/10.1007/978-1-349-14865-3

Purdon, S., Lessof, C., Woodfield, K., \& Bryson, C. (2001). Research methods for policy evaluation. Retrieved from https://www.researchgate.net/publication/236144404_Research_Methods_For_Policy_Evaluation

Soeharto. (2012). Pencapaian standar nasional pendidikan di Sekolah Menengah Kejuruan Daerah Istimewa Yogyakarta. CAKRAWALA PENDIDIKAN Jurnal Ilmiah Pendidikan, 31(1), 23-37. https://doi.org/10.21831/cp.v0i1.1464

Soenarto, S., Amin, M. M., \& Kumaidi, K. (2017). Evaluasi implementasi kebijakan Sekolah Menengah Kejuruan program 4 tahun dalam meningkatkan employability lulusan. Jurnal Penelitian dan Evaluasi Pendidikan, 21(2), 215-227. https://doi.org/10.21831/pep.v21i2.17076

Sukardi, \& Wardana, L. A. (2016). The study of service quality and competitiveness of secondary education in West Sumbawa. Management, 785, 853. https://doi.org/10.2991/icse-15.2016.86

Sumarno, S. (2009). Keefektifan program sekolah menengah kejuruan teknologi dan industri (SMKTI). Jurnal Penelitian dan Evaluasi Pendidikan, 13(1). http://dx.doi.org/10.21831/pep.v13i1.1403

Wahyuningtyas, R., Rusgiyono, A., \& Wilandari, Y. (2013). Analisis sektor unggulan menggunakan data PDRB (Studi kasus BPS Kabupaten Kendal tahun 2006-2010). Jurnal Gaussian, 2(3), 219-228. Retrieved from https://ejournal3.undip.ac.id/ index.php/gaussian/article/view/3667

Wong, P. K., Ho, Y. P., \& Autio, E. (2005). Entrepreneurship, innovation and economic growth: Evidence from GEM data. Small business economics, 24(3), 335-350. https://doi.org/10.1007/s11187-005-2000-1

Wong, P. K., Ho, Y. P., \& Singh, A. (2007). Towards an "entrepreneurial university" model to support knowledge-based economic development: the case of the National University of Singapore. World Development, 35(6), 941-958. https://doi.org/10.1016/j.worlddev.2006.05.007

Zhang, W. (2009). Issues of practical teaching in vocational-technical schools in China and their countermeasures. International Education Studies, 2(4), 75-78. https://doi.org/10.5539/ies.v2n4p75

\section{Copyrights}

Copyright for this article is retained by the author(s), with first publication rights granted to the journal.

This is an open-access article distributed under the terms and conditions of the Creative Commons Attribution license (http://creativecommons.org/licenses/by/4.0/). 